\title{
Cadmium, road dust and rheumatoid arthritis: an alternative hypothesis to general air pollution
}

\author{
Daniel Murphy ${ }^{*}$ and David Hutchinson
}

Keywords: Rheumatoid arthritis, dust, cadmium, air pollution, citrullination

\section{To the Editor}

We read the review "Is air pollution a risk factor for rheumatoid arthritis?" with great interest [1]. We agree that air pollution is a potential risk factor for rheumatoid arthritis (RA) in low-and-middle-income countries. As the authors correctly point out, epidemiological studies in high-income countries which have failed to demonstrate a link between air pollution and the risk of RA $[2,3]$, can not necessarily be generalised to individuals living in lowand-middle-income countries.

However, it remains that two large well conducted studies in North America have clearly demonstrated an increased risk of RA in those residing $\leq 50 \mathrm{~m}$ from a highway compared with residence $>150 \mathrm{~m}$ away $[4,5]$. This finding is not explained by industrial pollution per se as two studies in high income countries found no consistent association between air pollution and an increased RA risk $[2,3]$. If air pollution in high-income countries is not associated with the development of RA, what other factor can explain the risk for RA living in close proximity to a main road as opposed to just 150-200 m further away? We suggest a novel hypothesis of cadmium-containing road dust inhalation either by the roadside or within the home as a plausible explanation.

The lung is now considered to be an important initiating site of seropositive RA as a result of local anti-citrullinated peptide (anti-CCP) antibody generation [6]. Inhalation of cadmium has been hypothesised as a potential trigger for RA as cadmium links smoking, the most important etiological factor in the development of seropositive RA, and many of the other known contemporary risk factors such as low socio-economic class, regional clustering in the U.S. and specific occupations associated with RA [7]. Increased cadmium exposure in an animal model has

\footnotetext{
*Correspondence: Daniel.murphy@cornwall.nhs.uk

Rheumatology Department, Royal Cornwall Hospital, Truro, Cornwall, UK
}

recently been demonstrated to enhance disease activity of collagen induced arthritis [8].

Cadmium levels have been shown to markedly decrease within $20 \mathrm{~m}$ from the roadside [9]. Cadmium is a component of petrol and diesel fuel and was previously used as a curing agent in tires, a component of brake pads, alloyed with copper in the production of car radiators and in car paints. Additionally, asphalt concrete road surfacing contains appreciable amounts of cadmium [10]. We suggest that cadmium-laden ultrafine dust will occur in close proximity to busy roads as a result of both vehicular component and road surface wear, and vehicular fuel emissions. This would be particularly evident on fast moving roads where acceleration and hard braking is commonplace.

A number of nanoparticles, including silica, can induce lung citrullination via activation of cellular calcium channels with a subsequent rise in intracellular calcium and activation of peptidyl arginine deiminase and subsequent peptide citrullination [11]. Fine cadmium dusts have the potential to cause citrullination as cadmium is a potent activator of calcium channels and significantly raises intracellular calcium levels $[12,13]$.

Cadmium levels need not correlate with air pollution per se. This is exemplified by a US study demonstrating the mean concentration of cadmium in the air of 28 US cities was found to correlate with mortality rates from hypertension and coronary heart disease although indices of air pollution did not correlate with mortality from hypertension and coronary heart disease [14].

We suggest that further studies investigating the link between residing close to a main road and RA development take into account bodily cadmium levels as a co-founding factor as it is known that inhalation of road dust containing cadmium correlates with increased bodily levels of cadmium [15]. 


\section{Competing interests}

We confirm that this manuscript constitutes the original work of the authors detailed above and is not under consideration for publication elsewhere. The authors confirm that they have no conflicts of interest to declare in the preparation of this work, having equal data access and all had a role in preparation of the letter as detailed above.

\section{Received: 17 September 2015 Accepted: 2 October 2015}

\section{Published online: 12 October 2015}

\section{References}

1. Essouma M, Noubiap JJ. Is air pollution a risk factor for rheumatoid arthritis? J Inflamm. 2015;12:48.

2. Hart JE, Källberg H, Laden F, Bellander T, Kostenbader KH, Holqvist M, et al. Ambient air pollution exposures and risk of rheumatoid arthritis: results from the Swedish EIRA case-control study. Ann Rheum Dis. 2013;72(6):888-94.

3. Hart JE, Kalberg H, Laden F, Kostenbader KH, Yanosky JD, Klareskog R, et al. Ambient air pollution exposures and risk of rheumatoid arthritis in the Nurses' Health Study. Arthritis Care Res. 2013;65(7):1190-6.

4. Hart JE, Laden F, Puett RC, Kostenbader KH, Karlson WE. Exposure to traffic pollution and increased risk of rheumatoid arthritis. Environ Health Perspect. 2009;117:1065-9.

5. De Roos AJ, Koehoorn M, Tamburic L, Davies HW, Brauer M. Proximity to traffic, ambient air pollution, and community noise in relation to incident rheumatoid arthritis. Environ Health Perspect. 2014;122:1075-80.

6. Perry E, Kelly C, Eggleton P, De Soyza A, Hutchinson D. The lung in ACPA-positive rheumatoid arthritis: an initiating site of injury? Rheumatology. 2014:53(11):1940-50.

7. Hutchinson D. Cadmium, one of the villains behind the curtain: has exposure to cadmium helped to pull the strings of seropositive rheumatoid arthritis pathogenesis all along? Int J Rheum Dis. 2015;18(5):570-3.

8. Ansari MM, Neha, Khan HA. Effect of cadmium chloride exposure during the induction of collagen induced arthritis. Chem Biol Interact. 2015;238:55-65.

9. Benfenati E, Valzacchi S, Mariani G, Airoldi L, Fanelli RPCDD, PCDF. PCB, PAH, cadmium and lead in roadside soil: relationship between road distance and concentration. Chemosphere. 1992;24:1077-83.

10. Australian Government Department of the Environment National Pollutant Inventory. Cadmium and compounds. www.npi.gov.au/ resource/cadmium-and-compounds (accessed $10^{\text {th }}$ September 2015).

11. Mohamed BM, Verma NK, Davies AM, McGowan A, Crosbie-Staunton K, Prina-Mello A, et al. Citrullination of proteins: a common post-translational modification pathway induced by different nanoparticles in vitro and in vivo. Nanomedicine. 2012;7:1181-95.

12. Hinkle PM, Shanshala ED, Nelson EJ. Measurement of intracellular cadmium with fluorescent dyes. Further evidence for the role of calcium channels in cadmium uptake. J Biol Chem. 1992;267:25553-9.

13. Misraa UK, Gawdia G, Akabanib G, Pizzoa SV. Cadmium-induced DNA synthesis and cell proliferation in macrophages: the role of intracellular calcium and signal transduction mechanisms. Cell Signal. 2002;14:327-40.

14. Carroll RE. The Relationship of Cadmium in the Air to Cardiovascular Disease Death Rates. JAMA. 1966;198(3):267-9.

15. Mohmand J, Eqani SA, Fasola M, Alamdar A, Mustafa I, Ali N, et al. Human exposure to toxic metals via contaminated dust: Bio-accumulation trends and their potential risk estimation. Chemosphere. 2015;132:142-51.

\section{Submit your next manuscript to BioMed Central and take full advantage of:}

- Convenient online submission

- Thorough peer review

- No space constraints or color figure charges

- Immediate publication on acceptance

- Inclusion in PubMed, CAS, Scopus and Google Scholar

- Research which is freely available for redistribution 